\title{
HUBUNGAN ANTARA PENGETAHUAN DAN SIKAP REMAJA PUTRI DALAM PEMELIHARAAN VULVA HYGIENE SAAT MENSTRUASI DI SMA NEGERI 1 SENTANI KABUPATEN JAYAPURA
}

\author{
Seba Sintike Haba ${ }^{1}$, Kismiyati ${ }^{2}$, Viertianingsih Patungo ${ }^{1}$ \\ ${ }^{1}$ Prodi Keperawatan Stikes Jayapura, ${ }^{2}$ Politeknik Kesehatan Jayapura \\ Email: prodikep.stikesjypr@yahoo.com
}

\begin{abstract}
ABSTRAK
Salah satu perilaku pemeliharaan alat reproduksi wanita adalah dengan melakukan pemeliharaan vulva hygiene. Remaja putri yang berada dalam masa peralihan disertai dengan proses kematangan organ reproduksinya, perlu mendapatkan perhatian khusus. Penelitian ini dilakukan untuk mengetahui hubungan pengetahuan dan sikap remaja putri dalam pemeliharaan vulva hygiene saat menstruasi di SMAN 1 Sentani. Desain penelitian ini adalah analitik observasional menggunakan pendekatan cross sectional. Pengambilan sampel menggunakan teknik purposive sampling dan pengambilan data menggunakan kuesioner. Besar sampel dalam penelitian ini sebanyak 65 orang. Masing- masing variabel diteliti dengan menggunakan uji Statistik Spearman's dengan tingkat signifikan $\mathrm{p}<0,05$ untuk mengetahui hubungan dari masing-masing variabel. Hasil penelitian menunjukkan remaja putri yang berpengetahuan baik tentang pemeliharaan vulva hygiene sebanyak 63 responden $(96,9 \%)$. Sikap remaja putri tentang pemeliharaan vulva hygiene dalam kategori baik sebanyak 46 responden $(70,8 \%)$. Kemudian diperoleh hasil tentang pemeliharaan vulva hygiene dalam kategori baik sebanyak 46 responden $(70,8 \%)$. Untuk mengetahui hubungan antara ketiga variabel, digunakan uji statistik Rank Spearman's. Hasil analisis data tersebut adalah terdapat hubungan antara pengetahuan remaja putri terhadap pemeliharaan vulva hygiene saat menstruasi dibuktikan dengan $(\mathrm{p}=0,011)$, dan tidak terdapat hubungan antara sikap remaja putri terhadap pemeliharaan vulva hygiene saat menstruasi dibuktikan dengan $(\mathrm{p}=0,487)$.
\end{abstract}

Kata kunci: Pengetahuan, Sikap, Remaja Putri, Vulva Hygiene, Menstruasi 


\begin{abstract}
One of the care of female reproductive organ is caring the vulva hygiene. Adolescent who are in the transition and maturity process of reproductive organs, need special attention. This research aims to determine the correlation between knowledge and attitudes of adolescent in care of vulva hygiene during menstruation at SMAN 1 Sentani. This research design was observational analytic using cross sectional approach. Sampling technique using purposive sampling and to obtain data using questionnaire. 65 people were used in this research as the sample. Each variable analyzed by Spearman Statistical Test to determine the relationship ( $\mathrm{p}<0.05$ ). The result of the research showed that 63 respondents $(96.9 \%)$ were knowledgeable about the care of hygiene vulva. The attitude of the adolescent about the care of vulva hygiene were 46 respondents $(70,8 \%)$ in the quite much category. Then the results of the care of vulva hygiene were 46 respondents $(70,8 \%)$ in the quite much category. To determine the correlation between these three variables used Rank Spearman statistical test. The result of the data analysis is there is correlation between knowledge of adolescent to the care of vulva hygiene during menstruation ( $\mathrm{p}$ $=0.011$ ), and there is no correlation between the attitude of adolescent to the care of vulva hygiene during menstruation $(\mathrm{p}=0.489)$.
\end{abstract}

Keywords: Knowledge, Attitude, Adolescent, The Care of Vulva Hygiene, Menstruation 


\section{PENDAHULUAN}

Perawatan/pemeliharaan alat reproduksi atau alat kelamin salah satunya yaitu dengan melakukan vulva hygiene. Vulva hygiene merupakan perawatan diri pada organ genetalia bagian luar yang terdiri atas mons veneris yang terletak di depan simpisis pubis, labia mayora, labia minora, klitoris kemudian bagian yang terkait disekitarnya seperti uretra, vagina, perineum dan anus. Faktor-faktor yang mempengaruhi keberhasilan vulva hygiene adalah pengetahuan dan sikap. Jika pengetahuan remaja putri tentang vulva hygiene baik, maka sikap remaja putri tersebut juga baik. Sehingga dapat mengurangi angka kejadian dari keputihan dan infeksi alat kelamin bagian luar.

Masalah kesehatan reproduksi khususnya organ genetalia pada wanita bagian luar meliputi leucorrhoea, vulvitis dan lain-lain. Leukorea adalah keluarnya cairan jernih atau berwarna putih atau hijau atau kuning selain darah dari liang vagina di luar kebiasaan, baik berbau maupun tidak, serta disertai rasa gatal setempat. Vulvitis adalah suatu peradangan pada vulva atau organ kelamin wanita bagian luar. Salah satu penyebab terjadinya leukorea dan vulvitis yaitu oleh karena cara membersihkan alat kelamin (vulva hygiene) yang kurang benar saat menstruasi, misalnya cara cebok yang tidak benar, mencuci vagina dengan air kotor, pemakaian pembilas vagina yang berlebihan, dan penggunaan celana dalam yang tidak menyerap keringat.

$\begin{array}{llr}\text { Hygiene } & \text { saat } & \text { menstruasi } \\ \text { dipengaruhi } & \text { oleh } & \text { tingkat } \\ \text { pengetahuan } & & \text { pemeliharaan }\end{array}$

kesehatan reproduksi. Kurangnya pengetahuan masyarakat menjadikan mereka berpola pikir yang ada menjadi mitos (Andira, 2010).

Menyikapi remaja putri yang belum mengetahui cara menjaga personal hygiene yang benar saat menstruasi, peranan orang tua khususnya ibu sangat dibutuhkan untuk memberikan pengetahuan tentang pemeliharaan menstruasi (Utami, 2012). 
Gangguan saat menstruasi sangatlah luas, salah satunya terjadi iritasi atau rasa gatal di sekitar vulva dan lubang vagina diakibatkan kurang menjaga kebersihan genitalia eksternal yang mana daerah ini amat peka bila disentuh. Jika kulit vagina tergores oleh kuku yang tajam atau benda lain, walaupun pada permukaannya kelihatan tidak rusak, namun hal ini dapat menyebabkan infeksi sekunder. Seperti infeksi candida akut, vaginosis bakteri dan trikomoniasis. Jika hal ini terjadi maka akan membuat keadaan lebih buruk (Djajakusumah, 2011).

Menurut Peraturan Menteri Kesehatan RI Nomor 25 tahun 2014, remaja adalah penduduk dalam rentang usia 10-18 tahun. Menurut Badan Kependudukan dan Keluarga Berencana (BKKBN) rentang usia remaja adalah 10-24 tahun dan belum menikah. Di dunia diperkirakan kelompok remaja berjumlah 1,2 milyar atau $18 \%$ dari jumlah penduduk dunia (WHO, 2014).

\begin{tabular}{rrr}
\multicolumn{2}{c}{ Berdasarkan data } & Dinas \\
Kependudukan & Provinsi & Papua
\end{tabular}

2010, didapatkan data jumlah total penduduk di provinsi papua sebesar 43,5 juta jiwa atau sekitar 18\% dari jumlah keseluruhan penduduk di Indonesia. Data terbaru provinsi papua tahun 2014 didapatkan data total penduduk sebanyak 3.091.047 yang terdiri dari laki-laki 1.631.306 orang dan perempuan 1.459.741 orang. Jadi, selama kurun waktu 4 tahun, dari tahun 2010-2014 jumlah penduduk bertambah sebanyak 257.288 orang. Ini berarti setiap tahun bertambah sebanyak 64.416 orang atau 2,27 persen (Dinas Kependudukan Provinsi Papua, 2014).

Data penduduk berdasarkan usia di Kabupaten Jayapura dalam tahun 2015 total keseluruhan penduduk yang berusia 10-19 tahun sebanyak 24.591 jiwa yang terdiri dari laki-laki 12.940 orang dan perempuan 11.651 orang (Statistika Kabupaten Jayapura, 2015).

Seiring perubahan dan pertambahan jumlah penduduk di dunia, berbagai masalah kesehatan bermunculan. Salah satu penyebabnya adalah kurang pengetahuan yang dapat 
mempengaruhi status kesehatan seseorang. Maka diharapkan semua tenaga kesehatan dapat melakukan promosi kesehatan sebagai upaya tindakan preventif yang mempengaruhi pengetahuan, sikap, dan perilaku seseorang untuk memelihara kesehatan

(Notoadmodjo, 2012).

Berdasarkan penelitian Astuti (2009) didapatkan data bahwa sebanyak 130 sampel didapatkan $50 \%$ remaja memiliki pengetahuan buruk, $53.8 \%$ memiliki sikap negatif, dan $56.9 \%$ memiliki perilaku vulva hygiene kurang baik. Ini disebabkan karena masih ada remaja putri yang belum mengetahui cara personal hygiene yang baik dan benar, kapan harus mengganti pembalut, dan cara mencuci pembalut. Hal ini dipengaruhi oleh kurangnya pengetahuan kesehatan reproduksi pemeliharaan personal hygiene pada remaja putri dari orang tua maupun dari sekolah. Hal ini menyebabkan pengetahuan, sikap, perilaku remaja putri masih kurang.

Berdasarkan hasil wawancara dengan pihak sekolah dan pihak
Dinas Kesehatan Kabupaten Jayapura pada tanggal 9 Mei 2016, didapatkan data bahwa sudah pernah dilakukan penyuluhan dari Dinas Kesehatan Kabupaten Jayapura mengenai kesehatan reproduksi kepada siswa-siswi di SMA N 1 Sentani. Namun didapati dalam hasil survey bahwa masih kurang kesadaran dari remaja secara khusus remaja putri mengenai kesehatan reproduksi.

Berdasarkan laporan tahunan Puskesmas Sentani tahun 2015, sebanyak 56 remaja $(13,5 \%)$ menderita sifilis, 99 remaja (24\%) menderita uretritis, 175 remaja $(42,4 \%)$ menderita servisitis dan sebanyak 82 remaja $(19,9 \%)$ mengalami fluor albus.

Berdasarkan fenomena di atas, maka penulis tertarik untuk melakukan penelitian dengan judul "Hubungan antara pengetahuan dan sikap remaja putri dalam pemeliharaan vulva hygiene saat menstruasi pada siswi kelas X SMA Negeri 1 Sentani Kabupaten Jayapura Tahun 2016". 


\section{METODE PENELITIAN}

Desain penelitian yang digunakan dalam penelitian ini adalah analitik observasional dan menggunakan pendekatan cross sectional, dimana analitik observasional adalah analisis yang membandingkan suatu kejadian atau penyebab penyakit secara ilmiah dengan cara pengamatan untuk menjelaskan peristiwa dan kejadian yang sedang di teliti oleh peneliti. Sedangkan cross sectional pengumpulan data sekaligus pada suatu saat (Nursalam, 2013).

Tempat penelitian yang digunakan untuk penelitian ini di SMA Negeri 1 Sentani Kabupaten Jayapura. Pelaksanaan penelitian mulai dilakukan pada 25 Juli 2016. Populasi dalam penelitian ini adalah semua murid yang ada di kelas X IPA yang berjumlah 122 siswa di SMA N 1 Sentani.

Teknik sampling yang digunakan dalam penelitian ini adalah purposive sampling sehingga besar sampel dalam penelitian ini adalah 93 orang. Purposive sampling adalah metode penetapan responden untuk dijadikan sampel berdasarkan pada kriteria-kriteria tertentu.

Pertimbangan yang dilakukan oleh peneliti dalam pemilihan sampel adalah menentukan kriteria, dimana kriteria pemilihan terdiri dari kriteria inklusi dan eksklusi.

Dalam penelitian ini instrumen penelitian atau alat yang digunakan untuk pengambilan data adalah dengan menggunakan kuesioner. Alat pengumpulan data berupa kuesioner tentang pengetahuan dan sikap remaja putri dalam pemeliharaan vulva hygiene saat menstruasi.

Analisis bivariat yang digunakan dalam penelitian ini untuk melihat kemungkinan hubungan antara variabel independen dan variabel dependen dengan menggunakan analisis uji Spearman's Rank (Rho). Adapun analisis bivariat ini dilakukan untuk melihat ada tidaknya hubungan antara pengetahuan dan sikap remaja putri terhadap pemeliharaan vulva hygiene saat menstruasi. Melalui uji 
Spearman's Rank akan diperoleh nilai p, dimana penelitian ini digunakan tingkat kemaknaan sebesar 0,05 . Penelitian dikatakan bermakna jika mempunyai $\mathrm{p} \leq$ 0,05 yang berarti $\mathrm{H} 0$ ditolak dan Ha diterima dan dikatakan tidak bermakna jika mempunyai nilai $p$ > 0,05 yang berarti H0 diterima dan Ha ditolak.

\section{HASIL DAN PEMBAHASAN}

\section{Pengetahuan Remaja Putri}

Berdasarkan hasil, dari 65 responden, sebagian besar pengetahuan tentang vulva hygiene dalam kategori baik sebanyak 63 responden $(96,9 \%)$ dan responden dengan pengetahuan kurang sebanyak 2 responden $(3,1 \%)$.

Menurut Notoatmodjo (2012), pengetahuan adalah hasil dari tahu dan terjadi setelah seseorang melakukan pengindraan terhadap suatu objek tertentu. Dalam Kamus Besar Bahasa Indonesia (2005), pengetahuan adalah sesuatu yang diketahui berkaitan dengan proses pembelajaran. Proses belajar dipengaruhi berbagai faktor dari dalam, seperti motivasi dan faktor luar berupa sarana informasi yang tersedia, serta keadaan sosial budaya (Budiman, 2013).

Berdasarkan hasil penelitian ini, pengetahuan responden dalam kategori baik sebanyak 63 siswi (96,9\%). Ini dikarenakan nilai responden dalam menjawab kuesioner pengetahuan remaja putri dalam pemeliharaan vulva hygiene saat menstruasi sesuai kriteria yang telah ditentukan dan dipengaruhi oleh pengalaman yang didapat sejak menstruasi.

Umur responden dalam penelitian ini berkisar antara 15-18 tahun dimana umur tersebut termasuk kategori masa remaja tengah. Dengan bertambahnya umur akan mengubah kognitif dan psikologis seseorang. Semakin bertambahnya umur seseorang maka akan semakin bijaksana sehingga menambah pengetahuannya. Dengan begitu remaja putri akan semakin tahu tentang pemeliharaan vulva hygiene saat menstruasi. 
Sikap Remaja Putri

Berdasarkan hasil, dari 65 responden yang memiliki sikap tentang vulva hygiene dalam kategori baik sebanyak 46 responden $(70,8 \%)$, sedangkan responden dengan sikap cukup sebanyak 17 responden $(26,2 \%)$ dan responden dalam kategori sikap kurang sebanyak 2 responden $(3,1 \%)$.

Sikap adalah reaksi atau respon yang masih tertutup terhadap stimulus atau objek (Notoatmodjo, 2007). Sikap yang ada dalam diri seseorang memerlukan unsur respons dan stimulus. Kepuasan merupakan respon dari stimulus yang diterima. Output sikap pada seseorang dapat berbeda, jika suka maka seseorang akan mendekat, mencari tahu, dan bergabung, sebaliknya jika tidak suka, maka seseorang akan menghindar dan menjauh (Budiman, 2013).

Berdasarkan hasil penelitian yang didapat dari 65 remaja putri yang memiliki sikap dengan kategori baik sebanyak 46 respoden $(70,8 \%)$. Ini dapat dipengaruhi oleh faktor pengalaman pribadi. Dimana pengalaman remaja putri yang memiliki sikap baik tentang pemeliharaan vulva hygiene saat menstruasi ini bisa didapatkan ketika remaja putri tersebut mengalami gangguan alat kelamin bagian luar saat menstruasi dikarenakan kurang memperhatikan personal hygiene saat menstruasi dapat mengakibatkan terjadinya vulvitis. Ini diperkuat dari item pernyataan membersihkan alat kelamin harus menggunakan sabun mandi dengan skor terendah 163. Hal ini sesuai dengan teori bahwa sikap seseorang akan lebih muda terbentuk apabila pengalaman pribadi terjadi dalam situasi yang melibatkan faktor emosional.

Perhatian orang tua terutama ibu juga dapat membantu anak perempuannya untuk bersikap baik dalam menjaga kebersihan alat kelamin. Karena pada umumnya seorang perempuan tahu bahwa dirinya lebih mudah terkena infeksi saluran reproduksi (ISR) dibandingkan laki-laki karena 
saluran reproduksi wanita lebih dekat dengan anus dan saluran kencing.

Sikap remaja putri tentang pemeliharaan vulva hygiene saat menstruasi dalam kategori cukup sebanyak 17 responden $(26,2 \%)$. Dari 17 remaja putri yang memiliki sikap dalam kategori cukup dapat dipengaruhi oleh faktor lingkungan, dimana remaja putri akan dipengaruhi oleh tingkah laku dari teman-temannya. Hal ini sesuai dengan teori bahwa pada umumnya individu akan memiliki sikap yang searah dengan orang yang dianggap penting.

Sikap remaja putri tentang pemeliharaan vulva hygiene saat menstruasi minoritas dalam kategori kurang sebanyak 2 responden $(3,1 \%)$. Dari 2 remaja putri yang memiliki sikap dalam kategori kurang dapat dipengaruhi oleh pengetahuan remaja tersebut yang kurang. Hal ini sesuai dengan teori bahwa pengetahuan merupakan salah satu faktor yang mempengaruhi terbentuknya sikap seseorang.
Vulva hygiene merupakan hal yang penting bagi remaja putri untuk menjaga kesehatan serta kebersihan organ genitalia eksternal. Vulva hygiene mencakup cara menjaga dan merawat kebersihan organ genitalia eksternal dan organ genitalia internal. Jika vulva tidak dijaga kebersihannya dengan baik dan benar, maka infeksi bakteri dari luar dapat masuk ke vagina dan menimbulkan gangguan.

Pemeliharan Vulva Hygiene saat Menstruasi

Berdasarkan hasil penelitian menunjukkan bahwa perilaku dalam pemeliharaan vulva hygiene saat menstruasi dengan kategori perilaku baik sebanyak 46 responden $(70,8 \%)$ sedangkan responden yang memiliki perilaku cukup sebanyak 16 responden $(24,6 \%)$ dan 3 responden $(5,6 \%)$ memiliki perilaku kurang.

Menurut Elmart (2012), upaya kebersihan diri yang terkait organ reproduksi yaitu vulva hygiene. Vulva hygiene sendiri terdiri atas dua kata, yaitu vulva atau kelamin luar, dan hygiene 
yang berarti kebersihan. Jadi vulva hygiene saat menstruasi mencakup cara menjaga dan merawat kebersihan organ kelamin bagian luar.

Seseorang berpengetahuan baik tidak menjamin akan mempunyai sikap dan perilaku yang positif. Karena seseorang dalam menentukan sikap dan perilaku yang utuh selain ditentukan oleh pengetahuan, juga dipengaruhi oleh pikiran, keyakinan dan emosi yang memegang peranan penting.

\section{Hubungan Pengetahuan Remaja}

Putri terhadap Pemeliharaan

\section{Vulva Hygiene saat Menstruasi}

Berdasarkan hasil penelitian, menunjukkan bahwa hasil penelitian dari 65 remaja putri. Dilihat sebanyak 63 responden $(96,9 \%)$ berpengetahuan baik terhadap pemeliharaan baik sebanyak 46 responden $(73, \%)$, dari responden yang berpengetahuan baik masih terdapat pemeliharaan yang cukup sebanyak 15 responden $(23,8 \%)$. Sedangkan ada 2 responden yang berpengetahuan kurang. Namun terdapat sebanyak 1 responden (50\%) ada dalam pemelihaaan cukup dan 1 responden (50\%) ada dalam pemeliharaan kurang.

Setelah data diolah dari hasil penelitian didapatkan bahwa terdapat hubungan antara variabel pengetahuan dan variabel pemeliharaan vulva hygiene saat menstruasi, berdasarkan hasil uji Spearman's Rank diperoleh nilai $p$ value sebesar 0,011. Karena $\mathrm{p}<$ 0,05 artinya ada hubungan bermakna dimana terdapat hubungan pengetahuan terhadap pemeliharaan vulva hygiene saat menstruasi.

Hasil yang didapat dari tabulasi silang diatas jika remaja putri mempunyai pengetahuan baik tentu akan mempengaruhi sikap dan perilaku remaja putri tentang pemeliharaan vulva hygiene akan tetapi belum tentu memiliki perilaku pemeliharaan vulva hygiene yang baik ini dikarenakan beberapa faktor yang mempengaruhi perilaku seseorang.

$$
\text { Menurut Notoatmodjo }
$$
(2010), pengetahuan atau kognitif merupakan domain yang sangat 
penting untuk terbentuknya tindakan seseorang (ovent behavior). Berdasarkan pengalaman dan penelitian ternyata perilaku yang didasari oleh pengetahuan akan lebih langgeng dari pada perilaku yang tidak didasari oleh pengetahuan. Mengingat kembali terhadap suatu yang spesifik dari seluruh badan yang telah dipelajari atau yang telah diterima, oleh sebab itu tahu ini merupakan tingkat pengetahuan yang paling rendah.

Faktor-faktor yang mempengaruhi pengetahuan yaitu sosial ekonomi, pendidikan, dan pengalaman. Apabila status ekonomi baik, tingkat pendidikan akan tinggi, diiringi oleh peningkatan pengetahuan. Budaya berpengaruh terhadap tingkat pengetahuan karena informasi yang baru akan disaring dan disesuaikan dengan budaya yang ada, pendidikan yang tinggi akan berpengaruh pada penerimaan halhal baru dan dapat menyesuaikan diri dengan hal baru tersebut. Pengalaman berkaitan dengan umur dan pendidikan individu.
Pendidikan yang tinggi maka pengalaman akan luas dan semakin tua umur seseorang maka pengalaman akan bertambah (Notoatmodjo, 2010).

Dalam penelitian ini didapatkan hasil sebanyak 63 responden $(96,9 \%)$ remaja putri memiliki pengetahuan baik terhadap pemeliharaan vulva hygiene dalam kategori baik sebanyak 46 responden $(73,0 \%)$. Hal ini disebabkan jawaban dari pertanyaan dalam kuesioner berkaitan dengan tingkat pengetahuan remaja putri terhadap pemeliharaan vulva hygiene saat menstruasi mereka baik dan benar yaitu dengan cara: (1) menjaga dan merawat organ kewanitaan setiap hari dengan cara membasuh/membilas dengan air bersih sesudah BAB dan BAK, (2) setelah BAK membasuh daerah kewanitaan dari depan (vagina) kearah belakang (anus), (3) saat menstruasi mengganti pembalut 34 kali perhari, (4) menggunakan pakaian dalam berbahan katun, untuk mempermudah penyerapan keringat. Dapat dilihat dari hasil 
penelitian sebelumnya yang mempunyai sikap dan perilaku dilakukan Permatasari menunjukkan sebanyak 13 $(30,1 \%)$ remaja putri berpengetahuan baik, dan perilaku personal hygiene saat menstruasi dalam kategori baik sebanyak 13 responden $(24,5 \%)$. Ini dikarenakan remaja putri telah mengalami pengalaman menstruasi dan informasi yang didapatkan sehingga pengetahuan yang baik dan juga mempengaruhi perilaku yang baik dari seseorang.

Remaja putri yang memiliki pengetahuan baik terhadap pemeliharaan vulva hygiene dalam kategori cukup sebanyak 15 responden $(23,8 \%)$. Hal ini disebabkan karena perilaku remaja putri tidak berdasarkan pengetahuan dimana diperkuat dari jawaban atas pertanyaan dalam kuesioner tentang kebiasaan memakai pembalut > 6 jam. Didapatkan sebanyak 33 responden menjawab sering melakukan kebiasaan mengganti pembalut $>6$ jam.

Seseorang berpengetahuan baik tidak menjamin akan yang positif. Karena seseorang dalam menentukan sikap dan perilaku yang utuh selain ditentukan oleh pengetahuan, juga dipengaruhi oleh pikiran, keyakinan dan emosi yang memegang peranan penting (Notoadmodjo, 2010).

Dapat dilihat dari peneliti sebelumnya Permatasari dari 53 remaja putri terdapat 16 responden $(30,1 \%) \quad$ remaja putri berpengetahuan baik, dengan perilaku personal hygiene dalam kategori cukup sebanyak 11 responden (20,8\%). Perilaku seseorang akan dibentuk ketika adanya motivasi untuk melakukan sesuatu yang dianggap penting untuk dilakukan sedangkan sebuah keinginan saja tidak dapat menentukan hasil dari sebuah perilaku seseorang dibutuhkan kesadaran diri yang mana akan mendorong timbulnya kemauan dalam bertindak.

Hasil dalam penelitian ini, masih terdapat pengetahuan remaja putri dalam kategori kurang sebanyak 2 responden 
$(3,1 \%)$ terhadap pemeliharaan vulva hygiene saat menstruasi dalam kategori cukup sebanyak 1 responden $(50 \%)$. Hal ini sesuai dengan hasil penelitian Irma (2013), yang menunjukkan sebanyak 2 responden (6\%) memiliki pengetahuan kurang, dan 20 responden $(62,5 \%)$ memiliki perilaku cukup dalam merawat organ genetalia eksterna selama menstruasi. Hal ini dipengaruhi oleh proses belajar, dimana perubahan perilaku yang dihasilkan dari praktek-praktek dalam lingkungan kehidupan (Wawan \& Dewi, 2010).

Hasil

menunjukkan penelitian pemeliharaan vulva hygiene remaja putri dalam kategori cukup dapat dilihat sebanyak 34 responden menjawab kuesioner pemeliharaan dalam kategori sering menggunakan celana dalam harus berbahan katun agar mudah menyerap keringat. Ini berarti kebiasaan yang dibangun dalam lingkungan keluarga dan dapat dipraktekkan setiap hari oleh remaja putri.
Dalam penelitian ini juga terdapat remaja putri berpengetahuan kurang terhadap pemeliharaan vulva hygiene saat menstruasi dalam kategori kurang sebanyak 1 responden (50\%). Hal ini terbukti dalam jawaban kuesioner pemeliharaan vulva hygiene saat menstruasi masih kurang atau tidak benar seperti menggunakan sabun/zat kimia untuk membersihkan organ kewanitaan, tidak sering mengganti pembalut, cara membasuh organ genetalia eksternal yang dari belakang kedepan dan sebagainya, sehingga pengetahuan para siswi putri kurang dalam pemeliharaan vulva hygiene saat menstruasi.

Hal ini juga didukung oleh peneliti sebelumnya Irma (2013), sebanyak 2 responden $(6 \%)$ memiliki pengetahuan kurang, dan 12 responden $(37,5 \%)$ memiliki perilaku kurang dalam merawat organ genetalia eksterna selama menstruasi. Hal ini sesuai dengan teori pengetahuan dapat dipengaruhi oleh beberapa faktor salah satunya faktor lingkungan 
yang dimana menurut Mariner yang dikutip dalam Nursalam 2015, lingkungan merupakan seluruh kondisi yang ada disekitar manusia dan pengaruhnya dapat mempengaruhi perkembangan dan perilaku orang atau kelompok.

Lingkungan keluarga adalah sebuah dasar terbentuknya pengetahuan, perilaku, juga sikap seseorang. Dimana orang tua khusus ibu jika jarang mengajari atau memberikan informasi berkaitan tentang kesehatan reproduksi sehingga anak kerap tidak mendapatkan pengetahuan yang baik dari lingkungan disekitarnya. Pengetahuan akan mempengaruhi sikap yang kemudian menentukan baik buruknya perilaku seseorang untuk meningkatkan kesehatannya.

Hubungan Sikap Remaja Putri terhadap Pemeliharaan Vulva

\section{Hygiene saat Menstruasi}

Berdasarkan hasil dari 65 remaja putri, dilihat sebanyak 46 responden $(70,8 \%)$ yang memiliki sikap baik terhadap pemeliharaan dalam kategori cukup sebanyak 9 responden $(19,6 \%)$, dari responden yang memiliki sikap baik masih terdapat sebanyak 3 responden $(6,5 \%)$ ada dalam pemeliharaan kurang, sedangkan responden dengan sikap cukup sebanyak 17 responden $(26,2 \%)$ ada dalam pemeliharaan baik sebanyak 11 responden $(64,7 \%)$, dan sebanyak 2 responden $(3,1 \%)$ ada dalam sikap kurang, dimana dari responden yang memilki sikap kurang masih terdapat sebanyak 1 responden (50\%) ada dalam pemeliharaan baik tetapi masih ada responden yang memiliki sikap kurang namun pemeliharaannya cukup sebanyak 1 responden $(50 \%)$.

Setelah data diolah didapatkan dari hasil uji Spearman's Rank untuk mengetahui hubungan sikap remaja putri terhadap pemeliharaan vulva hygiene saat menstruasi mendapat hasil $\mathrm{p}$ value 0,487 karena $\mathrm{p} \geq 0,05$ sehingga tidak terdapat hubungan bermakna sikap remaja putri terhadap pemeliharaan vulva hygiene saat menstruasi. 
Hasil dari tabulasi silang diatas dilihat pendapat yang dikemukakan oleh Azwar dalam buku Wawan dan Wiwin (2010), sikap dipengaruhi oleh faktor orang lain yang dianggap penting selain keluarga khususnya orang tua, faktor dari lembaga pendidikan dan tenaga kesehatan juga sangat berpengaruh terhadap pembentukan sikap remaja putri, sikap remaja putri terbentuk bukan dibawa sejak lahir melainkan dibentuk atau dipelajari sepanjang perkembangan dalam hubungan dengan obyeknya.

Responden yang memiliki sikap baik terhadap pemeliharaan cukup sebanyak 9 responden $(19,6 \%)$. Dapat dilihat dari jawaban responden yang diberikan melalui pertanyaan seputar pemeliharaan vulva hygiene apakah anda saat menstruasi mengganti pembalut 3-4 kali perhari sebanyak 35 respoden menjawab sering melakukan perilaku demikian. Sikap yang baik belum dapat memastikan perilaku seseorang baik dalam mengaplikasikan sesuai dengan cara yang benar ini dikarenakan ada beberapa faktor diantaranya faktor lingkungan keluarga yang dapat mengubah sikap seseorang juga berdampak pada perilaku orang tersebut.

Ini didukung oleh penelitian yang dilakukan Handayani (2011), sebanyak 36 responden $(70,9 \%)$ memiliki sikap baik dan perilaku cukup dalam kebersihan organ genitalia eksterna sebanyak 16 responden (41,0\%). Hal ini dipengaruhi oleh faktor kultural atau kebudayaan seperti status sosial, lingkungan keluarga dan pendidikan juga merupakan faktor yang berarti dapat menentukan sikap manusia. Variabel psikologis dan kultural selalu saling mempengaruhi dalam rangka menimbulkan, memelihara atau mengubah sikap.

$$
\text { Responden yang memiliki }
$$
sikap baik terhadap pemeliharaan kurang sebanyak 3 responden $(6,5 \%)$. Dilihat dari hasil jawaban yang diberikan melalui pertanyaan seputar pemeliharaan vulva hygiene, seberapa seringnya mencukur rambut di sekitar 
kemaluan. Sebanyak 42 responden menjawab tidak pernah mencukur rambut kemaluan. Hal ini dipengaruhi faktor penguat mencakup informasi keluarga, teman sebaya, guru, dan lain-lain. Hal ini sejalan dengan peneliti sebelumnya Handayani 2011, sebanyak 36 responden $(70,9 \%)$ memiliki sikap baik dan perilaku kurang dalam kebersihan organ genitalia eksterna sebanyak 6 responden (50,0\%). Kurangnya sumber informasi yang didapat melalui orang tua, teman sebaya, tenaga kesehatan, media massa seperti koran, majalah karena faktor yang sangat dibutuhkan dalam pembentukan sikap seseorang terhadap kebiasaan yang baik sehingga perilaku menjaga kebersihan organ genetalia eksterna tidak benar.

Hasil penelitian yang didapat menunjukkan sebanyak 17 responden $(26,2 \%)$ memiliki sikap cukup terhadap pemeliharaan baik sebanyak 11 responden $(64,7 \%)$. Dapat dilihat dari hasil yang didapatkan melalui jawaban responden berdasarkan sikap remaja adalah 17 remaja putri setuju menggunakan pakaian dalam berbahan katun untuk mempermudah penyerapan keringat dan 11 responden memiliki pemeliharaan baik dengan menjawab pertanyaan seputar pemeliharaan vulva hygiene saat menstruasi apakah anda lebih sering menggunakan celana dalam berbahan nylon dari pada berbahan katun dan jawaban tiap responden berikan adalah tidak pernah menggunakan celana dalam berbahan nylon.

Sikap yang cukup dan memiliki pemeliharaan yang baik dipengaruhi oleh bentuk perilaku aktif yang ada dalam diri seseorang yang dapat diobservasi secara langsung. Sejalan dengan penelitian yang dilakukan oleh Wiji Utami (2014), terdapat remaja yang memiliki sikap cukup sebanyak 36 responden (63\%) dan kategori perilaku baik sebanyak 15 responden (26\%). Hal ini dipengaruhi oleh bentuk aktif perilaku seseorang yang nyata sebagai respons dari stimulus yang diterima. 
Menurut Azwar dalam buku Wawan dan Dewi (2010), struktur sikap terdiri dari 3 komponen yang saling menunjang yaitu: (1) komponen kognitif merupakan representasi apa yang dipercayai oleh individu pemilik sikap, (2) komponen afektif merupakan perasaan yang menyangkut aspek emosional. Aspek emosional inilah yang biasa berakar paling dalam sebagai komponen sikap dan merupakan aspek yang paling bertahan terhadap pengaruhpengaruh yang mungkin akan mengubah sikap seseorang, (3) komponen kognitif merupakan aspek kecenderungan berperilaku tertentu sesuai dengan sikap yang dimiliki oleh seseorang.

Dalam penelitian ini juga menunjukkan sebanyak 2 responden $(3,1 \%)$ ada dalam sikap kurang, dimana dari responden yang memilki sikap kurang masih terdapat sebanyak 1 responden (50\%) ada dalam pemeliharaan baik tetapi masih ada responden yang memiliki sikap kurang namun pemeliharaannya cukup sebanyak 1 responden (50\%).
Sikap yang kurang akan berdampak pada jarangnya perempuan memperhatikan kebersihan pada organ genetalia eksternanya. Apabila tidak merawat dengan benar, dapat menyebabkan berbagai macam akibat yang merugikan misalnya infeksi pada daerah organ gentalia eksterna. Hal ini didukung dengan jawaban responden membersihkan alat kelamin harus menggunakan sabun mandi dan jawaban responden setuju atas pernyataan tersebut sebanyak 26 responden. Ini dikarenakan remaja tidak mengetahui permasalahan seputar organ reproduksinya.

Sejalan dengan penelitian yang pernah dilakukan oleh Handayani 2011, responden yang memiliki sikap kurang dan memiliki perilaku baik adalah sebanyak 15 responden $(29,4 \%)$, responden yang memiliki sikap kurang dan memiliki perilaku cukup adalah sebanyak 23 responden $(59,0 \%)$. Hal ini dipengaruhi karena kurangnya sikap remaja terhadap perawatan organ kewanitaan dan juga kurang 
menggali informasi tentang pentingnya pemeliharaan organ reproduksi wanita sehingga pembentukan sikap dengan stimulus tidak didapatkan dengan demikian tidak adanya reaksi yang dapat ditunjukan dalam bentuk tindakan nyata.

Dari yang dipaparkan di atas asumsi peneliti bahwa sikap itu mempunyai kecenderungan stabil, sekalipun sikap itu dapat mengalami perubahan. Namun sikap itu dibentuk ataupun dipelajari dalam hubungannya dengan objek tertentu, berhubungan dengan hal-hal tersebut maka akan terlihat pentingnya faktor pengalaman, pengaruh orang yang dianggap penting, lembaga pendidikan, dan tenaga kesehatan dalam rangka pembentukan sikap juga dapat mempengaruhi perilaku remaja putri dalam pemeliharaan vulva hygiene saat menstruasi.

\section{KESIMPULAN}

1. Pengetahuan remaja putri tentang pemeliharaan vulva hygiene saat menstruasi di
SMAN 1 Sentani, didapatkan hasil dari 65 responden yaitu sebanyak 63 responden $(96,9 \%)$ diantaranya berada pada kategori berpengetahuan baik dan sebanyak 2 responden $(3,1 \%)$ dengan kategori berpengetahuan kurang.

2. Sikap remaja putri tentang pemeliharaan vulva hygiene saat menstruasi di SMAN 1 Sentani, menunkukkan bahwa dari 65 responden yang memiliki sikap tentang vulva hygiene dalam kategori baik sebanyak 46 responden (70,8\%), sedangkan responden dengan sikap cukup sebanyak 17 responden $(26,2 \%)$ dan responden dalam kategori sikap kurang sebanyak 2 responden $(3,1 \%)$.

3. Pemeliharaan vulva hygiene saat menstruasi di SMAN 1 Sentani, menunkukkan bahwa dari 65 responden, yang memiliki pemeliharaan vulva hygiene saat menstruasi dalam kategori baik sebanyak 46 responden $(70,8 \%)$, sedangkan responden dengan 
pemeliharaan cukup sebanyak 16 responden $(24,6 \%)$ dan responden dalam kategori pemeliharaan kurang sebanyak 3 responden $(4,6 \%)$.

4. Terdapat hubungan bermakna antara pengetahuan remaja putri terhadap pemeliharaan vulva hygiene saat menstruasi di SMAN 1 Sentani, dimana nilai $p$ value $<0,05 \%$ (nilai $\mathrm{p}$ $0,011<0,05 \%)$.

5. Tidak terdapat hubungan bermakna antara sikap remaja putri terhadap pemeliharaan vulva hygiene saat menstruasi di SMAN 1 Sentani, dimana nilai $p$ value $\geq 0,05 \%$ (nilai $p$ $0,487 \geq 0,05 \%$ ).

\section{SARAN}

1. Bagi Institusi Pendidikan Pihak sekolah perlu memberikan dorongan kepada anak didiknya untuk secara aktif mencari tahu informasi mengenai kesehatan reproduksi secara khusus pemeliharaan vulva hygiene saat menstruasi. Selain itu diperlukan penambahan pendidikan kesehatan reproduksi dalam mata pelajaran biologi.

2. Bagi Siswi SMAN 1 Sentani Remaja putri perlu mencari informasi tentang bagaimana cara pemeliharaan vulva hygiene saat menstruasi yang baik dan benar. Hal itu diperlukan agar masalahmasalah kesehatan reproduksi bisa cepat diketahui dan cepat pula dalam proses penangannya.

3. Bagi Tenaga Kesehatan

Diharapkan bagi tenaga kesehatan agar dapat melakukan penyuluhan dan promosi seputar pengetahuan dan sikap terhadap pemeliharaan vulva hygiene saat menstruasi guna meningkatkan pengetahuan para remaja tentang pentingnya pemeliharaan vulva hygiene dan melakukan demonstrasi cara menjaga kebersihan daerah genital.

4. Bagi Peneliti Lain

Penelitian ini masih bisa dikembangkan dalam 
penelitian selanjutnya dengan faktor-faktor lain yang masih berhubungan dengan pengetahuan dan sikap dalam pemeliharaan vulva hygiene saat menstruasi. Faktor yang dapat dikembangkan antara lain faktor-faktor yang mempengaruhi pengetahuan, sikap dan macam-macam informasi yang didapat responden untuk meningkatkan perilaku pemeliharaan vulva hygiene saat menstruasi.

\section{DAFTAR PUSTAKA}

Andira, D. (2010). Seluk Beluk Kesehatan Reproduksi Wanita Yogyakarta:

Apluss. Books

Budiman, N. (2013). FaktorFaktor yang Berhubungan dengan Praktik Wanita Pekerja Seks (Wps) Jalanan Dalam Upaya Pencegahan Ims da Hiv/Aids di Sekitar AlunAlun dan Candi Prambanan Kabupaten Klaten (Thesis). Semarang: UNDIP. http://eprints.undip.ac.id/1 8461, (diakses 28 Juli 2016)

Dinas Kependudukan Propinsi Papua (2014)

Djajakusumah, T. (2011). Penatalaksanaan Pruritus Anogenital. Surabaya: 2223

Handayani. (2011). Hubungan Pengetahuan, Sikap dan Perilaku Remaja Putri Tentang Kebersihan Organ Genitalia Eksterna di Madrasah Tsanawiyah Pembangunan

Irma. (2013). Perilaku Remaja Putri Dalam Merawat Organ Genitalia Eksterna Selama Menstruasi Pada Siswi Kelas XI di MAN Dolopo Kabupaten Mediun Notoadmodjo, S. (2010). Metodologi Penelitian Kesehatan. Rineka Cipta Notoadmodjo, S. (2012). Promosi Kesehatan dan Perilaku Kesehatan. Jakarta: Rineka Cipta.

Nursalam. (2013). Konsep dan Penerapan Metodologi 
Penelitian

Ilmu

Keperawatan. Jakarta: PT.

Rineka Cipta

Permatasari. (2013). Hubungan

Pengetahuan Remaja Putri

Kelas $\quad X \quad$ Tentang

Menstruasi Dengan

Perilaku Personal Hygiene

saat Menstruasi di SMKN

02 Bangkalan

Utami. (2012). Hubungan gizi dan

keluhan menstruasi pada

remaja. Bogor: Fakultas

Pertanian, Institusi

Pertanian Bogor.

Wawan., \& Dewi. (2010). Teori \& Pengukuran Pengetahuan Sikap dan Perilaku

Manusia, Yogyakarta,

Nuha medika. 